\title{
Dietary fiber characteristics and mineral availability from treated and non-treated brown rice
}

\section{Trinidad Palad Trinidad", Aida Casibang Mallillin, Marco Pomida de Leon, James David Santos Alcantara}

Food and Nutrition Research Institute, Department of Science and Technology, Dpartment of Science and Technology, Gen. Santos St., Bicutan, Taguig City, Metro Manila 1631, Philippines

Email address:

trinidadtp@yahoo.com.ph (T. P. Trinidad)

\section{To cite this article:}

Trinidad Palad Trinidad, Aida Casibang Mallillin, Marco Pomida de Leon, James David Santos Alcantara. Dietary Fiber Characteristics and Mineral Availability from Treated and Non-Treated Brown Rice. Agriculture, Forestry and Fisheries. Vol. 3, No. 5, 2014 , pp. $401-404$. doi: $10.11648 /$ j.aff.20140305.22

\begin{abstract}
Background: Brown rice has greater mineral content than milled rice. However, due to high dietary fiber and phytic acid content, mineral absorption may be suppressed. Objective: To determine the dietary fiber characteristics and mineral availability from treated and non-treated brown rice. Materials and Methods: Four varieties of cooked brown rice were used in the study and the same treated to extend the shelf-life of brown rice. Freeze-dried samples were analysed for proximate composition, dietary fiber, phytic acid, iron, zinc and calcium content using standard methods. Mineral availability and dietary fiber fermentation were determined in vitro. Results: The dietary fiber content of treated brown rice $(11.0 \pm 0.6-11.7 \pm 0.1)$ was significantly greater than that of non-treated brown rice $(5.5 \pm 0.5-6.4 \pm 0.2 ; \mathrm{P}<0.05)$. The mineral content and availability from treated and non-treated brown rice did not differ significantly except for mineral availability. Dietary fiber and phytic acid did not show inhibitory effect on mineral availability from both brown rices. The dietary fiber content from both brown rices was fermentable producing short chain fatty acids with greater amounts of propionate. Conclusion: Treated and non-treated brown rice are good sources of minerals and dietary fiber, found to be fermentable, and did not inhibit mineral availability.
\end{abstract}

Keywords: Brown Rice, Dietary Fiber, Minerals

\section{Introduction}

Brown rice is better than polished rice because it has greater vitamins and minerals than polished rice. However, brown rice contains greater amounts of dietary fiber and phytic acid which may interfere with mineral absorption.

Brown rice has been shown to have greater iron availability in vitro than milled rice but lower zinc and calcium availability (1). However, in vitro digestion and ferritin formation in cultured human intestinal Caco-2 cells of cooked rice digests showed higher iron absorption (ferritin formed) on milling of five brown rice varieties (2). Studies conducted in Thailand on polished and unpolished rice revealed that iron absorption from polished rice was greater than unpolished rice (3-4). However, because of the high iron content of unpolished rice the absolute amount of iron absorbed from the polished and unpolished rice did not differ significantly (4-5).

Interest in dietary fiber is growing due to the multiple benefits this dietary components has on health. These fiber components cannot be digested in the small intestines but are carried into the large intestines. If the fiber is fermentable in the large intestine/colon it can release the mineral for absorption (6) and provide substrates for the microorganisms that reside in the colon (7). Fermentation by microorganisms results in the formation of a number of end products that influence physiology and metabolism like the short chain fatty acids e.g. acetate, propionate and butyrate (6-7).

Studies on the interactive effects of dietary fiber and mineral availability from brown rice are scarce. The study will determine the dietary fiber characteristics and mineral availability from different varieties of treated and non-treated brown rice.

\section{Materials and Methods}

Test Foods: Four varieties of treated and non-treated brown rice were used in the study as follows: Rc160, Rc216, PHB71 
and SL8. Brown rice varieties were treated to extend its shelf-life by inhibiting lipase activity to lessen rancidity. All food samples were analysed as freeze-dried cooked brown rices.

Analytical Methods: The proximate analysis of test foods was determined using AOAC methods (8). Total iron, zinc and calcium (9) as well as total dietary fiber and phytic acid (11) was analyzed using AOAC method (10). Tannic acid content of brown rice was also determined (12).

\section{In Vitro Digestion and Dialysis (6)}

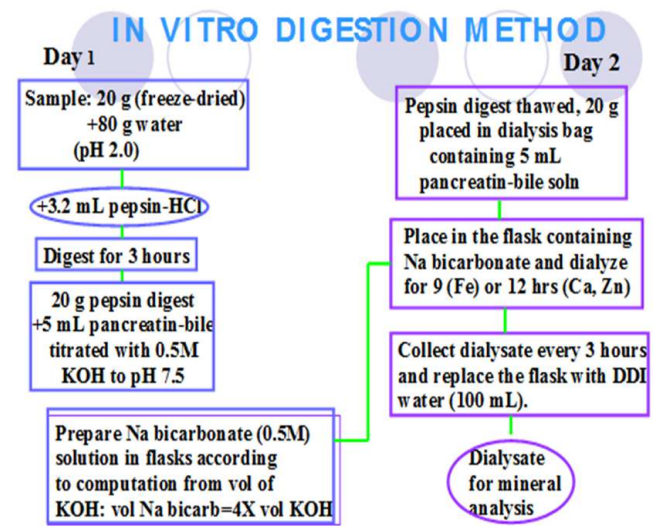

Figure 1. In vitro digestion and dialysis simulating conditions in the stomach and small intestine.

Twenty grams of freeze-dried cooked brown rice samples were weighed in 250-mL Erlenmeyer flask. The samples were homogenized and the $\mathrm{pH}$ was adjusted to 2.0 using $6 \mathrm{~N} \mathrm{HCl}$. Pepsin- $\mathrm{HCl}$ solution $(3.2 \mathrm{~mL})$ was added and the resulting solution was incubated for three hours at $37^{\circ} \mathrm{C}$ in a water bath shaker (100rpm). From the digested sample solution, twenty grams was aliquoted and added $5 \mathrm{~mL}$ of pancreatin-bile solution. The $\mathrm{pH}$ was adjusted to 7.5 using $0.5 \mathrm{M} \mathrm{KOH}$. Four times the volume of the $\mathrm{KOH}$ used was equivalent to the volume of $0.5 \mathrm{MNaHCO} 3$ in $100 \mathrm{~mL}$ dialysis solution. Another $20 \mathrm{~g}$ of pepsin-digested sample solution was weighed in a dialysis bag (Spectrum Lab) plus $5 \mathrm{~mL}$ pancreatin-bile solution. The dialysis bag was immersed in the bicarbonate solution. The mixture was incubated for a total of $12 \mathrm{hrs}$ at the same condition as the pepsin digestion. The dialysates were collected every $3 \mathrm{hrs}$, replacing with $100 \mathrm{~mL}$ of double deionized water. The dialysates were analyzed for mineral content using AAS. Dialyzable minerals was read in an Atomic Absorption Spectrometer and was used as a measure of mineral availability for absorption in the small intestine (Figure1).

\section{In Vitro Fermentation $(6,13)$}

Freeze dried cooked brown rice samples were fermented in vitro using human fecal inoculum. A $0.5 \mathrm{~g}$ of the test food was weighed in a serum bottle. Forty $(40) \mathrm{mL}$ of fermentation media (mix $2 \mathrm{~L}$ deionized water, $1 \mathrm{~L} 0.5 \mathrm{M}$ sodium bicarbonate buffer solution, $1 \mathrm{~L}$ macromineral solution, $5 \mathrm{~mL}$ of $0.1 \%$ resazurin), and $2 \mathrm{~mL}$ reducing solution (a mixture of $1.25 \mathrm{~g}$ cysteine- $\mathrm{HCl}+50$ pellets of potassium hydroxide in $100 \mathrm{~mL}$ deionized water and $1.25 \mathrm{~g}$ sodium sulfide in $100 \mathrm{~mL}$ deionized water) were added to the serum bottle and flushed with carbon dioxide until colorless. The bottles were sealed with rubber stoppers and aluminum seal and stored at $4^{\circ} \mathrm{C}$. Samples were sealed with rubber and aluminum cap prior to storage at $4^{\circ} \mathrm{C}$. The next day the bottles were placed in a water bath for $1-2$ hours at $37^{\circ} \mathrm{C}$. A $10-\mathrm{mL}$ fecal inoculum (1:15 dilution of fresh feces from a human volunteer) was added into each bottle and the mixture incubated for 24 hours at $37^{\circ} \mathrm{C}$. The fermented digest was filtered and read in a high pressure liquid chromatography (HPLC) to measure short chain fatty acids against a volatile acid standard mix (SUPELCO, Philadelphia, USA).

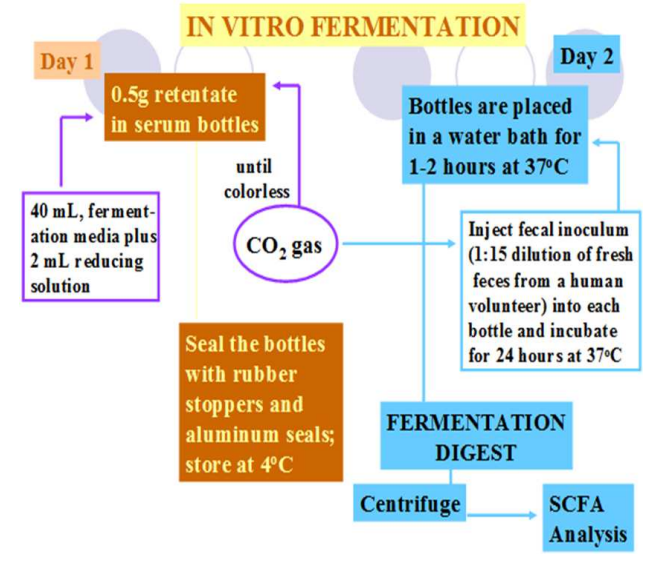

Figure 2. In vitro fermentation of dietary fiber simulating conditions in the colon.

\section{Statistical Analysis}

Differences between samples were determined by repeated measures analysis of variance and Duncan's Multiple Range Test using SAS Program.

\section{Results}

All varieties of brown rice were good sources of protein and carbohydrates (Table 1). PHB 71 has the highest fat content while SL8 the highest protein content. The best source of carbohydrates among the different varieties was Rc 216.

Table 1. Proximate Composition of Different Varieties of Cooked Brown Rice, g/l00 g Sample

\begin{tabular}{lllll}
\hline Brown Rice & Rc 160 & Rc 216 & PHB71 & SL8 \\
\hline Moisture & 67.0 & 62.1 & 67.6 & 65.5 \\
Ash & 0.5 & 0.6 & 0.4 & 0.6 \\
Protein & 3.2 & 3.6 & 2.6 & 3.9 \\
Fat & 1.1 & 1.2 & 1.4 & 1.3 \\
Carbohydrates & 28.2 & 32.5 & 28.0 & 28.7 \\
\hline
\end{tabular}

The best source of iron, zinc and calcium among the different varieties was PHB 71. In general, there were no significant differences in mineral content between non-treated and treated brown rices in different varieties except for SL8 for iron, Rc216 and PHB71 for zinc, and Rc160 and PHB71 for calcium (Table 2; $\mathrm{P}<0.05)$. Similar results were obtained for iron and zinc availability for non-treated and treated brown rices except for 
Rc160 for iron and Rc216 and PHB71 for zinc. For calcium non-treated and non-treated brown rice (Table 3; $\mathrm{P}, 0.05$ ). availability only Rc216 did not differ significantly between

Table 2. Mineral content of non-treated and treated brown rice, $\mathrm{mg} / 100 \mathrm{~g}$ Sample (Mean \pm SEM)

\begin{tabular}{|c|c|c|c|c|c|c|}
\hline \multirow{2}{*}{ Rice Variety } & \multicolumn{2}{|l|}{ Iron } & \multicolumn{2}{|l|}{ Zinc } & \multicolumn{2}{|l|}{ Calcium } \\
\hline & Non-Treated & Treated & Non-Treated & Treated & Non-Treated & Treated \\
\hline Rc160 & $0.70 \pm 0.10^{\text {ay }}$ & $0.70 \pm 0.10^{\text {ay }}$ & $1.50 \pm 0.10^{\text {ay }}$ & $1.60 \pm 0.10^{\mathrm{ax}}$ & $24.70 \pm 1.30^{\mathrm{az}}$ & $21.50 \pm 0.90^{\text {by }}$ \\
\hline Rc216 & $1.14 \pm 0.04^{\mathrm{ax}}$ & $1.11 \pm 0.05^{\mathrm{ax}}$ & $1.18 \pm 0.02^{\mathrm{bz}}$ & $1.27 \pm 0.06^{\mathrm{ay}}$ & $26.20 \pm 0.20^{\text {ay }}$ & $25.60 \pm 1.50^{\mathrm{ax}}$ \\
\hline PHB71 & $1.23 \pm 0.09^{\mathrm{ax}}$ & $1.10 \pm 0.03^{\mathrm{ax}}$ & $1.73 \pm 0.01^{\mathrm{ax}}$ & $1.65 \pm 0.01^{b x}$ & $28.60 \pm 0.60^{\mathrm{ax}}$ & $26.90 \pm 0.20^{\mathrm{bx}}$ \\
\hline SL8 & $1.12 \pm 0.01^{\mathrm{bx}}$ & $1.04 \pm 0.03^{\text {ay }}$ & $1.18 \pm 0.02^{\mathrm{az}}$ & $1.25 \pm 0.08^{\mathrm{ay}}$ & $21.00 \pm 1.86^{\mathrm{az}}$ & $21.90 \pm 0.20^{\text {ay }}$ \\
\hline
\end{tabular}

${ }^{\mathrm{ab}}$ denote significant differences between non-treated and treated brown rice at $\mathrm{P}<0.05$

${ }^{\mathrm{xyz}}$ denote significant differences between brown rice varieties at $\mathrm{P}<0.05$.

Table 3. Mineral availability of non-treated and treated brown rice, $\mathrm{mg} / 100 \mathrm{~g}$ Sample (Mean \pm SEM)

\begin{tabular}{|c|c|c|c|c|c|c|}
\hline \multirow{2}{*}{ Rice Variety } & \multicolumn{2}{|l|}{ Iron } & \multicolumn{2}{|l|}{ Zinc } & \multicolumn{2}{|l|}{ Calcium } \\
\hline & Non-Treated & Treated & Non-Treated & Treated & Non-Treated & Treated \\
\hline Rc160 & $9.3 \pm 0.2^{\mathrm{az}}$ & $5.8 \pm 1.6^{\mathrm{bz}}$ & $9.4 \pm 0.3^{\text {ay }}$ & $5.5 \pm 0.7^{\text {by }}$ & $19.2 \pm 0.2^{\mathrm{ax}}$ & $14.2 \pm 0.5^{\text {by }}$ \\
\hline Rc216 & $12.6 \pm 0.5^{\mathrm{ax}}$ & $12.1 \pm 1.5^{\mathrm{ax}}$ & $16.9 \pm 0.5^{\mathrm{ax}}$ & $4.2 \pm 0.8^{\text {by }}$ & $10.7 \pm 5.0^{\text {byz }}$ & $17.7 \pm 0.9^{\mathrm{ax}}$ \\
\hline PHB71 & $11.2 \pm 0.6^{\text {ay }}$ & $10.6 \pm 0.3^{\mathrm{ax}}$ & $7.9 \pm 0.9^{\mathrm{az}}$ & $6.8 \pm 0.4^{\mathrm{ax}}$ & $9.5 \pm 2.2^{\mathrm{az}}$ & $7.7 \pm 2.0^{\mathrm{az}}$ \\
\hline SL8 & $8.9 \pm 0.9^{\mathrm{az}}$ & $7.8 \pm 0.2^{\text {ay }}$ & $6.6 \pm 0.7^{\mathrm{az}}$ & $7.9 \pm 1.1^{\mathrm{ax}}$ & $14.5 \pm 1.6^{\text {ay }}$ & $8.9 \pm 1.5^{\mathrm{bz}}$ \\
\hline
\end{tabular}

${ }^{\mathrm{ab}}$ denote significant differences between non-treated and treated brown rice at $\mathrm{P}<0.05$

${ }^{\mathrm{xyz}}$ denote significant differences between brown rice varieties at $\mathrm{P}<0.05$.

Table 4. Dietary fiber and short chain fatty produced after fiber fermentation from treated and non-treated brown rice, Mean \pm SEM.

\begin{tabular}{|c|c|c|c|c|}
\hline \multirow{2}{*}{$\begin{array}{l}\text { Brown Rice } \\
\text { Varieties } \\
\end{array}$} & \multirow{2}{*}{$\begin{array}{l}\text { Dietary Fiber } \\
\mathrm{g} / 100 \mathrm{~g}\end{array}$} & \multicolumn{3}{|c|}{ Short Chain Fatty Acids, $\mathrm{mg} / \mathrm{g}$} \\
\hline & & Acetate & Propionate & Butyrate \\
\hline Rc160 & & & & \\
\hline Non-Treated & $6.3 \pm 0.0^{\mathrm{b}}$ & $28.5 \pm 0.2^{\mathrm{a}}$ & $1208.0 \pm 31.6^{\mathrm{a}}$ & $2.9 \pm 0.3^{a}$ \\
\hline $\begin{array}{l}\text { Treated } \\
\text { Rc } 216\end{array}$ & $11.1 \pm 0.1^{\mathrm{a}}$ & $20.7 \pm 2.4^{b}$ & $1133.8 \pm 29.4^{b}$ & $2.2 \pm 0.1^{\mathrm{b}}$ \\
\hline Non-Treated & $6.2 \pm 0.2^{b}$ & $39.5 \pm 1.4^{b}$ & $1193.0 \pm 60.1^{\mathrm{a}}$ & $1.5 \pm 0.1^{\mathrm{a}}$ \\
\hline $\begin{array}{l}\text { Treated } \\
\text { PHB71 }\end{array}$ & $11.0 \pm 0.1^{\mathrm{a}}$ & $41.4 \pm 1.7^{\mathrm{a}}$ & $938.4 \pm 39.0^{b}$ & $1.0 \pm 0.1^{\mathrm{b}}$ \\
\hline Non-Treated & $5.5 \pm 0.5^{b}$ & $5.4 \pm 1.0^{b}$ & $1006.2 \pm 10.2^{\mathrm{a}}$ & $2.6 \pm 0.3^{a}$ \\
\hline $\begin{array}{l}\text { Treated } \\
\text { SL8 }\end{array}$ & $11.0 \pm 0.6^{\mathrm{a}}$ & $7.2 \pm 0.5^{\mathrm{a}}$ & $980.6 \pm 28.8^{\mathrm{a}}$ & $2.1 \pm 0.1^{\mathrm{b}}$ \\
\hline Non-Treated & $6.4 \pm 0.2^{b}$ & $6.9 \pm 0.4^{\mathrm{a}}$ & $611.7 \pm 97.3^{b}$ & $0.2 \pm 0.0^{\mathrm{c}}$ \\
\hline Treated & $11.7 \pm 0.1^{\mathrm{a}}$ & $6.7 \pm 0.0^{\mathrm{a}}$ & $977.0 \pm 91.3^{\mathrm{a}}$ & $0.8 \pm 0.0^{\mathrm{a}}$ \\
\hline
\end{tabular}

${ }^{\text {abc }}$ denote significant differences between non-treated and treated brown rices at $\mathrm{P}<0.05$

Table 5. Phytic and tannic acid content from non-treated and treated brown rice, Mean $\pm S E M$

\begin{tabular}{llll}
\hline \multirow{2}{*}{ Rice Variety } & \multicolumn{2}{l}{ Phytic Acid, mg/100 g Sample } & Tannic Acid, mg/100 g Sample \\
\cline { 2 - 4 } & Non-Treated & Treated & Non-Treated \\
\hline Rc160 & $130.6 \pm 1.0^{\text {bz }}$ & $149.3 \pm 1.2^{\text {az }}$ & $19.4 \pm 1.0^{\text {ay }}$ \\
Rc216 & $143.6 \pm 0.6^{\text {by }}$ & $185.3 \pm 1.0^{\text {ay }}$ & $10.2 \pm 3.3^{\text {az }}$ \\
PHB71 & $224.7 \pm 6.1^{\text {ax }}$ & $220.5 \pm 1.3^{\text {ax }}$ & $19.9 \pm 0.4^{\text {ay }}$ \\
SL8 & $253.7 \pm 9.5^{\text {aw }}$ & $249.4 \pm 3.4^{\text {aw }}$ & $30.1 \pm 0.7^{\text {bx }}$ \\
\hline
\end{tabular}

${ }^{\mathrm{ab}}$ denotes significant differences between non-treated and treated brown rice at $\mathrm{P}<0.05$

${ }^{\text {wxyz }}$ denotes significant differences between rice varieties at $\mathrm{P}<0.05$

All varieties of non-treated and treated brown rices were good sources of dietary fiber with treated significantly greater than that of the non-treated brown rices (Table $4 ; \mathrm{P}<0.05$ ). Fermentation of dietary fiber simulating conditions in the colon from non-treated and treated brown rices resulted in the production of short chain fatty acids with propionate $>$ acetate $>$ butyrate Table 4; $\mathrm{P}<0.05$ ). Phytic acid content of non-treated brown rice differed significantly with treated brown rice except for PHB71 and SL8 (Table 5; $\mathrm{P}<0.05$ ). All rice varieties contained low tannic acid content, $<100$ $\mathrm{mg} / 100 \mathrm{~g}$ sample (Table 5).

\section{Discussion}

The lower mineral availability observed from treated brown rice in comparison to non-treated brown rice may be due to the reduced production of free fatty acids due to control of lipase activity during the treatment of brown rice. A study has shown that free fatty acids may have a role in increasing iron absorption in rats (14). The study suggested that the ferrous iron formation in the lumen may be followed by complexation with free fatty acids, yielding lipophilic complexes that may be 
taken up by the mucosal cells, thus increase iron absorption. Other studies showed that oleic acid promotes iron uptake by brush border vesicles from ferrous iron solution (15), and long chain fatty acids especially palmitic and oleic acid increased ferrous uptake by red cell membranes (16). It is possible that different fatty acids have different effects on iron absorption. Another study (17) reported that long chain fatty acids enhanced intestinal mucosal uptake of zinc. The same mechanism may be true for calcium.

The significantly higher dietary fiber content of treated brown rice than that of its corresponding non-treated brown rice may also be due to the fact that during the treatment, the production of free fatty acid is reduced.

Mineral availability in the presence of dietary fiber may not result in the reduction of available minerals for absorption if the dietary fiber is fermentable (6). Minerals can bind with dietary fiber in the small intestinal conditions but if the dietary fiber is fermentable in the colon can be released for absorption in the colon (6). This may be true for brown rice's high fiber-high mineral interaction observed in this study.

The dietary fiber in all varieties of non-treated and treated brown rices was fermentable in vitro and produced short chain fatty acids with propionate greater than acetate and butyrate. This result has some health significance. Propionate has been shown to inhibit the activity of the enzyme HMG-CoA reductase, the limiting enzyme for cholesterol synthesis and may therefore have an important role in the prevention for risk of cardiovascular and coronary heart diseases (18).

In conclusion, non-treated and treated brown rice are good sources of minerals and dietary fiber. Mineral availability was not affected by the high dietary fiber content of all varieties of brown rices. The dietary fiber present in brown rices studied were fermentable in vitro, and produced more of propionate shown to have some important role in inhibiting cholesterol synthesis. A nutrition intervention study is recommended to validate the promising health and nutritional benefits of brown rice varieties used in this study.

\section{Acknowledgement}

The authors wish to thank Dr. Rosario S. Sagum, Melissa S. Borlagdan, Amster Fei P. Baquiran, Theressa F. Aviles, Kristine Bernadette B.Cid, Zoilo B. Villanueva and Mark Ryan Q. Ibardaloza for their technical assistance.

The study was funded by the Department of Science and Technology -Grants-in-Aid (DOST-GIA) through the Philippine Council for Industry, Energy and Emerging Research and Development (PCIEERD).

There is no conflict of interest in the publication of this paper.

\section{References}

[1] Feliciano RRA. 200a. Mineral availability from brown rice and milled rice: an in vitro assessment. Thesis, Department of Physical Sciences and mathematics, University of the Philippines (Manila), Manila, Philippines.
[2] Prom-u-Thai C, Huang L, glan RP, Welch RM, Fukai S, Rerkasem B. 2006. Iron bioavailability and the distribution of anti-Fe nutrition biochemicals in the unpolished, polished grain and bran fraction of five geneotypes. J Sci Food Agric 86: 1209-1215.

[3] Tuntowiroon M, Sritonkul N, Hulten-Rossander L, Pleehachinda R, Suawanik R, Brune M, Hallberg L. 1990. Rice and iron absorption in man. Eur J Clin Nutr 44:489-497.

[4] Sisrichakwal PP, Tuntawiroon M, Sritongkul N, Kamchan A, Inchak T. 2006. Bioavailability of iron from high iron rice. In: Bioavailability 2006; Optimizing Dietary Strategies for better health in developing countries book of abstracts, Institute of Nutrition,Mahidol University, Bangkok, Thailand. P. 22.

[5] Trinidad TP, Mallillin AC, Sagum RS, Briones DP, Encabo RR, Juliano BO. 2009. Iron absorption from brown rice/brown rice-based meal and milled rice/milled rice-based meal. Int $\mathrm{J}$ Food Sc Nutr 60(8):688-93.

[6] Trinidad TP, Wolever TMS, Thompson LU. 1996. Availability of calcium for absorption in the small intestine and colon from diets containing available and unavailable carbohydrates: an in vitro assessment. Intl J Food Sc Nutr 47:83-88.

[7] Gray J. 2006. Dietary fiber, definition, analysis, physiology and health. ILSI Europe Concise Monograph Series. P.8-9.

[8] Association of Official Analytical Chemists. 2000. In: Horwitz $\mathrm{W}$, editor. Official method of analysis 920.7, 923.03, 925.10, 922.06. $17^{\text {th }}$ ed. AOAC Arlington, VA, USA vols I and II.

[9] Association of Official Analytical Chemists 1995 a. Cereal foods. In: Cunniff P, editor. Official methods of analysis $16^{\text {th }} \mathrm{ed}$. AOAC, Arlington, VA, USA. pp 1-49.

[10] Association of Official analytical Chemists. 1995 b. Official method of analysis 991.43 . Total, soluble and insoluble dietary fiber in foods. AOAC, Arlington, VA, USA. pp 7-9.

[11] Association of Official Analytical Chemists. 1986. Official method of analysis, phytate in foods: anion exchange method. AOAC, Arlington, VA, USA. 69:667-670.

[12] Earp CF, Ring SH, Rooney LW. 1981. Evaluation of several methods to determine tannins in sorghum with varying kernel characteristics. Cereal Chem 58:134-138.

[13] McBurney and Thompson LU. In vitro fermentabilities of purified fiber supplements. J Food Sci 1987; 54:347-350.

[14] Kapsokefalou M, Miller DD. (1993) Lean beef and beef fat interact to enhance non-heme iron absorption in rats. J Nutr 123:1429-1434

[15] Simpson RJ, Peters T (1987) Transport of ferrous across lipid bilayers: possible role of free fatty acids. Biochim Biophys Acta 898:187-195.

[16] Quian M, Eaton JW. (1991) Iron translocation by free fatty acids. Am J Pathol 139:1425-1434.

[17] Wapnir RA, Lee SY. (1990) Zinc intestinal absorption effect of free fatty acids and triglycerides. $J$ trace Elem Exp Med 3:255-265.

[18] Chen WJL, Anderson JW, Jenkins DJA. (1984) Propionate may mediate the hypocholesterolimic effects of certain soluble fibers in cholesterol-fed rats. Proc Soc Exp Biol Med. 175:215-218. 